\title{
LCD DISPLAY LEGIBILITY INFLUENCED BY TYPEFACES AND COLOUR CONTRASTS
}

\author{
Gregor Franken, Maruša Pangerc, Klementina Možina \\ University of Ljubljana, Faculty of Natural Sciences and Engineering, \\ Department of Textiles, Graphic Arts and Design, Ljubljana, Slovenia
}

\begin{abstract}
The evolution of high resolution displays, especially liquid crystal displays (LCD) that are among the most commonly used ones, has contributed to a larger circle of display readers. Despite high resolutions, problems in the legibility of typefaces still occur. Many typefaces may well be readable in print, but cause more difficulties when being read on displays. The aim of this study was to examine the influence of colour contrast on the legibility on LCDs to establish which type style is appropriate for a coloured text to be legible. Two different, specially designed typefaces for display use (one transitional, i.e. Georgia, and one sans-serif, i.e. Verdana) were tested in a satisfactory light-dark contrast of three different colour combinations involving five colours, i.e. dark grey (\#1A1A1A) on white (\#FFFFFF), dark blue (\#142451) on light grey (\#D9D9D9) and red (\#C62026) on light grey. The reading speed and fixations were analysed with an eye-tracking device Tobii 120X. Different texts in both typefaces at 12 pt (16 px), in 130\% leading and all colour combinations were displayed on a 24-inch LCD display. The forty tested individuals were between 19 and 22 years old. The results showed that the selection of a particular colour combination and contrast greatly affects the speed of reading and legibility. Less visible colour combinations of text and background were read more slowly than the more contrasting or visible ones at both typefaces. At both typefaces, it was seen that at a slower reading speed, more fixations were needed and vice-versa. It might also be concluded that the transitional typeface Georgia is more legible than the sans-serif typeface Verdana. Nevertheless, it appears that different colour combinations had different reading speeds at different typefaces (transitional vs sans-serif). An appropriate contrast and colour combination can facilitate legibility on displays.
\end{abstract}

Key words: colour contrast, eye-tracking technology, LCD display, legibility, reading, typography

\section{INTRODUCTION}

The evolution of high resolution displays, especially liquid crystal displays (LCD) that are among the most commonly used ones, has contributed to a larger circle of display readers. Despite high resolutions, problems in the legibility of typefaces still occur. Many typefaces may well be readable in print, but cause more difficulties when being read on displays.

The communication through a page or a display requires from the reader to translate symbols into meaning. Legibility refers to how easily this process is performed. To make reading possible, the text must be visible and recognisable; however, visibility and recognition are influenced by the typographical choice (Reynolds, 1988; Možina, 2001). Legibility and the reading process can be studied by tracking eye movement. Reading does not occur as a continuous movement of the eyes along the lines of a text, but rather as a sequence of rapid eye movements (saccades) and individual fixations. Fixations are short stops, which typically last between 200 and 250 ms (Abadi, 2006; Rayner et al, 2001) at individual words or groups of words that (within their duration) enable the brain to process information.

A large number of studies on legibility points to its importance. There are some typographic characteristics to be observed to make a text more legible. For a small type size, it is known that the differences in stroke weight and typographic tonal density (TTD) are significant (Možina et al, 2010; Rat et al, 2011), since they influence text legibility. Furthermore, a number of other typographic characteristics needs to be observed in order to make a text more legible, i.e. distinctive character features (counter shape), $x$-height, ascender, descender, serifs, contrast (stroke weight), set width, type size, leading (i.e. space between lines) etc (Franken et al, 2015; Možina, 2001; Reynolds, 1988; Tracy, 2003).

For better visibility of information, colour can be of use as well (White, 1996). Most typefaces are designed to be read as black letters on a white background and they in this manner achieve optimum legibility. When reading large amounts of type, the contrast of black and white is what readers are most accustomed to (Carter, 1997; Možina, 2001). To use colour for better typographic visibility, the contrast is poorer and we therefore have to take into consideration some recommendations (Carter, 1997; Možina, 2001; White, 1996). As type decreases in size, colour contrast has to increase in strength (Carter, 1997; 
Možina, 2001). Letter and word spacing, and leading affect type colour (TTD). Similarly, when letter and word spacing and leading increase, TTD decreases (Carter, 1997; Keyes, 1993; Možina, 2001). Therefore, when colour is used to improve visibility, larger type size or black typefaces or sans-serif typefaces need to be used. Furthermore, larger leading should be applied when colour is used for typography or background or both (Carter, 1997; Možina, 2001). To attract the reader's attention, blue and red colours are often used with white background (Pušnik, 2016). The red colour is associated with danger, energy or warmth (Thussu, 2007). It can activate an avoidance motivation, and enhance performance and detailoriented cognitive tasks (Mehta et al, 2009), and in turn, it can lead to greater attention. The blue colour, on the other hand, is supposed to represent trust, hope and serenity (Thussu, 2007). Despite the subdued tone, the combination of blue and white can affect the recipient and is a visible source of additional information (Thussu, 2007).

The legibility study (Franken et al, 2018) of different typefaces in different light-dark contrasts with different backgrounds displayed on an LCD display showed that a better contrast (however not maximum, i.e. black on white) increases the reading speed. Therefore, the aim of this study was to examine the influence of colour combination on the legibility on LCD displays to establish which type style is suitable for a coloured text to be legible.

\section{EXPERIMENTAL}

Two different, specially designed typefaces for display use - one transitional, i.e. Georgia, and one sansserif, i.e. Verdana (McLean, 1996; Možina, 2003) - were tested in three different colour combinations involving five colours, i.e. dark grey (\#1A1A1A) on white (\#FFFFFF) (Combination 1), dark blue (\#142451) on light grey (\#D9D9D9) (Combination 2) and red (\#C62026) on light grey (\#D9D9D9) (Combination 3).

In controlled laboratory conditions (ISO 3664, 2009), the reading speed and fixations were analysed with an eye-tracking device Tobii 120X. The texts in both typefaces at 12 pt (16 px), in 130\% leading and all colour combinations were displayed on a 24-inch LCD display with the resolution of $1900 \times 1200$ pixels at a $120 \mathrm{~Hz}$ refresh rate. In each typeface and each colour combination, a different text was presented to the tested individuals. We used six different texts from National Geographic (Slovenian edition) with the length of between 97 and 115 words, comprising between 10 and 13 lines (Figures 1 and 2).

»Če ti zdrsne, se ne boš mogel ustaviti. Zgrmel boš v prepad, « je bevsknil Rich Rudow. Navadno ga nič ne vrže iz tira, toda še predobro je vedel, da to ni kraj, kjer bi si lahko privoščil nepazljivost. Bila sva v prepadni steni kakšnih 1000 metrov nad reko Kolorado, na vrhu slikovite, v rečni zavoj ujete planote Great Thumb Mesa, ki moli z južnega roba Velikega kanjona kot premec velikanske ladje. Če vam je uspelo priti tako daleč in stojite na robu Thumba, se do reke ne morete spustiti brez plezalne opreme, kopneče zaloge hrane $v$ nahrbtniku pa vam ne dopuščajo vračanja po poti, po kateri ste prišli.

Figure 1: Sample of text paragraph with Verdana typeface 
Počepnem v travo, da bi si pobliže ogledala žival, ki se opoteka proti meni. Stara je približno štiri mesece, velika kot nogometna žoga, ima rahlo izbuljene oči in zagotovo je mehka in prijetnega vonja kot mlad kužek. Čutim neustavljivo željo, da bi jo dvignila in stisnila k sebi. Prav ta ljubkost je eden od razlogov, da je orjaški panda mednarodna znamenitost in hkrati kitajski kulturni simbol, gospodarska zlata jama in vir nacionalnega ponosa - Kitajska je namreč edina država, kjer še živijo ti azijski medvedi. Ves svet spremlja njena vztrajna prizadevanja, da bi se pande ohranili v naravnem okolju - v nekaterih pogledih je pri tem neverjetno uspešna.

Figure 2: Sample of text paragraph with Georgia typeface

The time required to read 600 characters (in seconds) and the number of fixations were calculated. Forty tested individuals were between 19 and 22 years old with normal or corrected-to-normal vision. In line with recommendations (ISO 9241, 2012), they were positioned $60(+/-1) \mathrm{cm}$ from the display. The texts were set in a CSS style sheet and displayed as a HTML document. In this way, we ensured a precise display of texts in the chosen size. The texts were shown in the centre of the display. The display sequence varied using the Latin square design, which was used for counterbalancing the order of texts.

\section{RESULTS AND DISCUSSION}

Figure 3 shows the average influence of the used colour combinations on the speed of reading. Figure 4 shows the influence of the used typefaces and colour combinations on the speed of reading. Figure 5 shows the influence of used colour combinations on the number of fixations. Figure 6 shows the influence of the used typefaces and colour combinations on the number of fixations.

On average, the reading speed was the fastest at the combination of the red text on light grey background (Combination 3) (cf. Figure 3). The reading speed was the slowest at the blue text on light grey text (Combination 2) (cf. Figure 3), regardless of the used typeface (cf. Figure 4). At all examples, the texts prepared with Georgia were read the fastest (cf. Figure 4). On average, the texts prepared with the Verdana typeface were read the slowest, the only exception was dark grey text on white background (Combination 1). Verdana is a sans-serif typeface and should thus have better legibility than a transitional typeface. Obviously, at this type size (16 px), big counter size, wide letters and thick stroke width led to lower reading speed. The interaction between a greater number of fixations (cf. Figures 5 and 6 ) and slower reading was noticed, especially at the Verdana typeface. A larger counter size gave more fixations and consequently resulted in slower reading. On the other hand, the typeface Georgia, which was read faster, needed less fixations.

It was also interesting that the red text on light grey background (Combination 3) gave the fastest reading speed (cf. Figure 3) and the smallest number of fixations (cf. Figure 5), since this colour combination has the smallest light-dark contrast among the used colour combinations. Most likely, the unusual colour combination for a longer text (not only titles or a short text) held more attention by the readers. It was surprising that the blue and light grey colour combination (Combination 2) with a strong enough 
light-dark contrast gave the worst legibility. Nevertheless, the reason is probably in the distribution of cones sensitive to short-wavelength light out of the fovea centralis, as there are more at the peripheral retina (Krauskopf, 1998). There should be no problem with larger objects in blue, while the typefaces with bigger counter sizes in smaller type sizes in blue obviously worsen legibility.

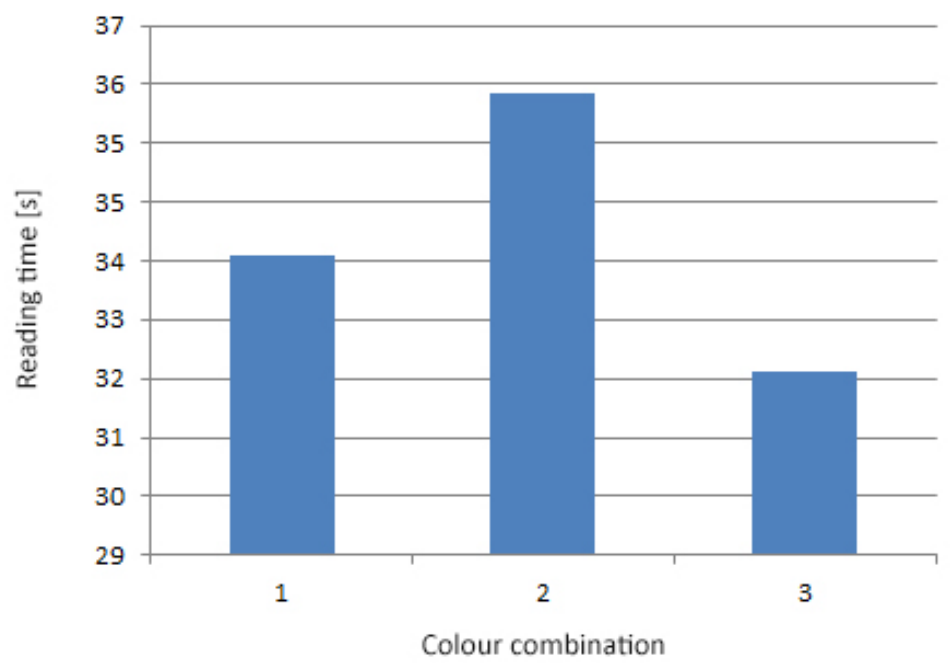

Figure 3: Average reading time [s] at used colour combinations

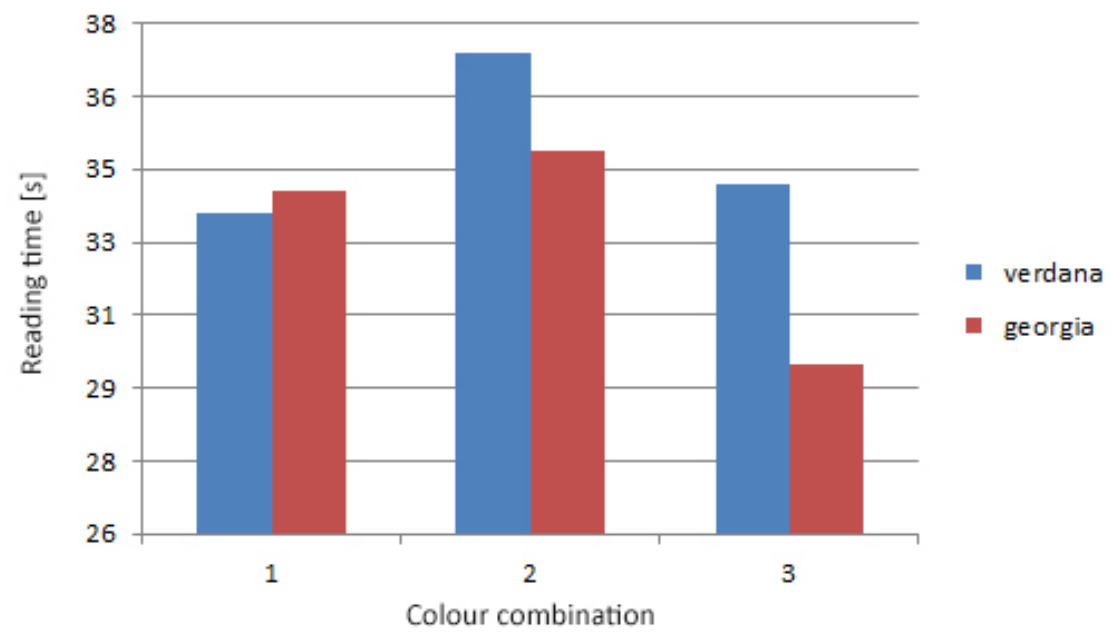

Figure 4: Reading time [s] at used typefaces in different colour combinations

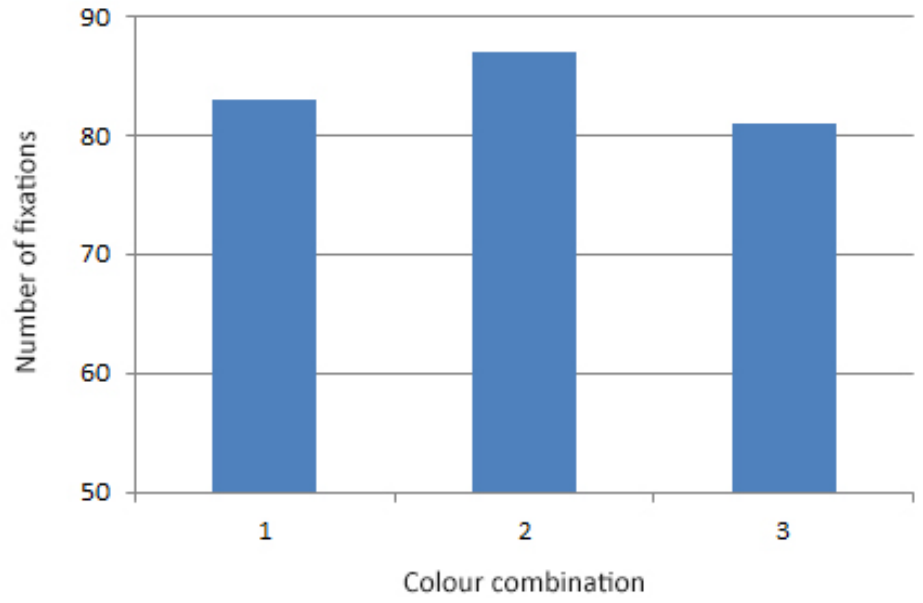

Figure 5: Number of fixations at used colour combinations 


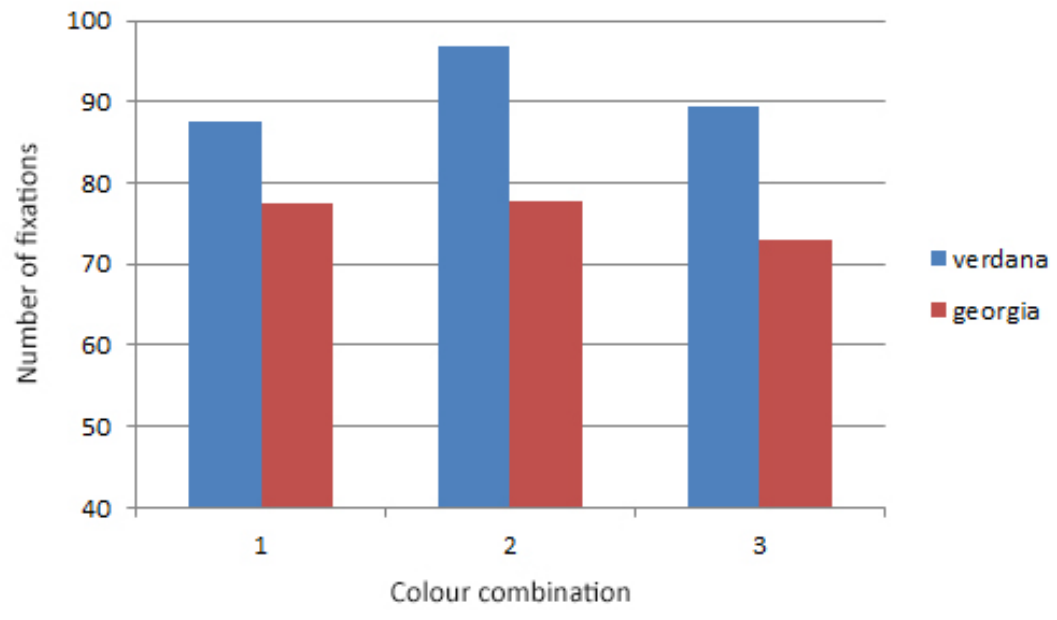

Figure 6: Number of fixations at used typefaces in different colour combinations

\section{CONCLUSION}

The results of the study showed that the selection of a particular colour combination and contrast greatly affects the speed of reading and legibility. Less contrasting or visible colour combinations of the text and background were read more slowly, i.e. blue and light grey, than the more contrasting or visible ones at both typefaces. At both typefaces, it was seen that at slower reading speed, more fixations were needed and vice-versa. It might also be concluded that the transitional typeface Georgia is more legible than the sans-serif typeface Verdana. Nevertheless, it appears that different colour combinations had different reading speeds at different typefaces (transitional vs sans-serif). Consequently, in order to be able to give an appropriate suggestion for usable display legibility, the study should be thought through with more diverse colour combinations and contrasts.

\section{REFERENCES}

[1] Abadi, R. V.: "Vision and eye movements", Clinical and Experimental Optometry 89, 55-56, 2006. doi: 10.1111/j.1444-0938.2006.00026.x.

[2] Carter, R.: "Working with computer type", (Rotovison, Crans, 1997), pages 30-37.

[3] Franken, G., Podlesek, A., Možina, K.: "Eye-tracking Study of Reading Speed from LCD Displays: Influence of Type Style and Type Size", Journal of Eye Movement Research 8(1), 1-8, 2015.

[4] Franken, G., Pangerc, M., Možina, K.: "Impact of Colour Combinations on LCD Display Legibility", Proceedings of AIC Lisboa 2018: colour \& human comfort 2018, (AIC: Lisbon, 2018), page 6.

[5] International Organization for Standardization, ISO 3664: Graphic technology and photography Viewing conditions, International Organization for Standardization, 2009.

[6] International Organization for Standardization, ISO 9241-303: Ergonomics of human-system interaction - Part 303: Requirements for electronic visual displays, International Organization for Standardization, 2012.

[7] Keyes, E.: "Typography, color, and information structure", Technical Communication 4(4), 638-654, 1993.

[8] Krauskopf, J.: "Color Vision: Color for Science, Art and Technology", (Elsevier, Amsterdam, 1998), pages $97-121$.

[9] McLean, R.: "The Manual of typography", (Thames and Hudson, London, 1996), page 60.

[10] Mehta, R., Zhu, R. J.: "Blue or Red? Exploring the effect of color on cognitive task performances", Science, 323 (5918), 1226-1229, 2009. doi:10.1126/science.1169144.

[11] Možina, K.: "Barva v tipografiji", Interdisciplinarnost barve, part 1, (Društvo koloristov Slovenije, Maribor, 2001), pages 341-364.

[12] Možina, K.: "Knjižna tipografija”, (University of Ljubljana Filozofska fakulteta, Oddelek za bibliotekarstvo in Naravoslovna fakulteta, Ljubljana, 2003), pages 109-212. 
[13] Možina, K., Medved, T., Rat, B., Bračko, S.: "Influence of Light on Typographic and Colorimetric Properties of Ink Jet Prints", Journal of Imaging Sciences and Technology 54 (6), 060403-1-0604038, 2010. doi:10.2352/J.ImagingSci.Technol.2010.54.6.060403.

[14] Pušnik, N.: "Vpliv barve in tipografije na hitrost zaznavanja napisov na konvencionalni in mobilni televiziji", PhD thesis, University of Ljubljana, Ljubljana, 2016.

[15] Rat, B., Možina, K., Bračko, S., Podlesek, A.: "Influence of Temperature and Humidity on Typographic and Colorimetric Properties of Ink Jet Prints", Journal of Imaging Sciences and Technology 55(5), 050607-1-050607-8, 2011. doi: 10.2352/J.ImagingSci.Technol.2011.55.5.050607.

[16] Rayner, K., Foorman, B., Perfetti, C., Pesetsky, D., Seidenberg, M.: "How Psychological Science Informs the Teaching of Reading", Psychological Science in the Public Interest Monograph 2, 31-74, 2001. doi: 10.1111/1529-1006.00004.

[17] Reynolds, L.: "Legibility of Type", Baseline 10, 26-29, 1988.

[18] Thussu, D. K.: "News as Entertainment: The rise of global infotainment", (Sage, London, 2007), pages $43-45$.

[19] Tracy, W.: "Letters of Credit: A View of Type Design", (David R., Boston, 2003), pages 30-32.

[20] White, J. V.: "Color for impact", (Strathmoor Press, Berkeley, 1996), pages 3-22.

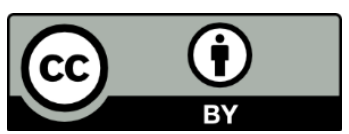

(C) 2018 Authors. Published by the University of Novi Sad, Faculty of Technical Sciences, Department of Graphic Engineering and Design. This article is an open access article distributed under the terms and conditions of the Creative Commons Attribution license 3.0 Serbia

(http://creativecommons.org/licenses/by/3.0/rs/). 